\title{
Assessment of Socio-economic and Health Status of Fisherwomen Involved in Coir Retting in Dickwella Secretariat Division, Matara District
}

\author{
A.G.L.A.S. Kumara*, N.Y. Hirimuthugoda ${ }^{1}$ and U. Edirisinghe ${ }^{2}$ \\ Postgraduate Institute of Agriculture \\ University of Peradeniya \\ Sri Lanka
}

\begin{abstract}
Coir retting yards are concentrated along the southern coastal line and specially women folk, find this work as the source of their principal income for the family in off seasons of fishing. The study was conducted in the Dickwella secretariat division to study the impact of coir retting on the socio-economic and health status of fisher women involved in coir retting. Random sample of 35 coir retting women involved in coir retting was selected. The necessary data of the location and families were collected by using questionnaires, interviews and discussions. Data obtained were statistically analyzed by using Statistical Package for Social Science (SPSS) software. Water quality parameters, such as $\mathrm{pH}$, temperature, $\mathrm{BOD}, \mathrm{COD}, \mathrm{NO}_{3}^{-}-\mathrm{N}$ and conductivity were analyzed. All the water quality parameters were not in permissible ranges. The average household size and daily net income of the coir retting families involved were 4.5 and Rs. 612.50, respectively. Eighty nine percent has obtained primary education while $9 \%$ and $2 \%$ have gained secondary and tertiary education respectively. It is obvious that these people do not have any access to other employment opportunities except coir retting due to lack of education. The results revealed that the coir retting industry of this area is an activity that is intricately interwoven with the social and economic structure. Field survey results indicated that $57 \%$ of the sample suffered from job-oriented disease like skin disease, blindness, headache, back bone pains and respiratory disease. Rotted husk release more organic pollutants and they highly affect the water quality parameters. Therefore, it is a difficult task to save these women from these occupational hazards unless some new affordable technique is introduced. Majority of the households (70\%) fall within a low socio-economic status with a deepening poverty background depicted by low educational achievement and occupational status.
\end{abstract}

Keywords: Coir retting, fisherwomen, fisher's family, health status, socio-economic status

\section{INTRODUCTION}

The fisheries sector plays a significant role in the national economy of Sri Lanka by generating export earnings and providing employment as well as a cheap protein source for the nation. Its contribution to Gross Domestic Production (GDP) though marginal (1\%), the sector is directly combined with the lives of approximately $50 \%$ of the population of the country that live in the coastal areas. However, in many developing countries, fisheries and

\footnotetext{
${ }^{1}$ Department of Animal Science, Faculty of Agriculture, University of Ruhuna, Mapalana, Sri Lanka

${ }^{2}$ Department of Animal Science, Faculty of Agriculture, University of Peradeniya, Peradeniya, Sri Lanka

Author for correspondence: gunawardana@gmail.com
} 
poverty go hand in hand. Although many fishers are poor, fisheries industry is capable of generating a great wealth (Anon, 2009) to the country.

The fish production and the number of active fishermen in Sri Lanka have increased considerably in 2008 when compared to previous years. However, fish yield per fishermen remained the same as in the previous year. This is an important problem, because the increase in fish production does not necessarily increase the income of fishermen. More effort should be taken to identify less income groups of fishermen and promote alternative fishing and non-fishing activities to increase their household income (Anon, 2009).

The coir (coconut fibre) business, is essentially a cottage industry, which mostly employs fisherwomen in southern coastal area. It provides an additional income source for fisher's family. This income assists fisher families during the monsoon season when the sea is too rough for fishing. During this time coir spinning forms the only source of income for the fisher families. An estimated $10 \%$ of fibre production is generated from traditional coir retting in the southern coastal region (Oxfam, 2006).

In the process of coir industry, husks are separated from the nuts and retted in lagoons up to ten months. The retted husks are then manually beaten with wooden mallets to produce the golden fibre. However, the coir retting yards have imposed a cost on the environment, fish and human health and biodiversity. This industry provides a significant quantity of organic matter to the environment. The retting process used in coir fibre production causes a significant water pollution. Cellulose and lignin get flushed out of the enclosures and pollute adjacent water bodies (Immanuel et.al., 2006). Among the major organic pollutants are pectin, pectosan, tannin, toxic polyphenols and several types of bacteria including salmonella (Woolly et.al., 1997). These pollutants harm human, mangrove forests as well as the entire biodiversity of the surrounding areas. However, reported work on the effect of coir retting on socio-economic and health status of coir retting families in Sri Lanka is scarce. The objective of this study was to assess the socio-economic status and health status of coir retting families.

\section{MATERIALS AND METHODS}

\section{Study design}

The study was conducted in Dickwella secretariat division of Matara district, located in the southern part of Sri Lanka from November 2009 to December of 2010. The necessary data from the location were collected by questionnaires, interviews and discussions from 35 families selected randomly. A semi-structured questionnaire was developed to get information about the socio-economic status of coir retting families. After pre-testing, the questionnaire was modified according to cultural sensitivity. Secondary data sources were also obtained from relevant reports, published and unpublished literature.

\section{Water quality analysis}

Water quality parameters such as temperature $\left({ }^{\circ} \mathrm{C}\right)$ and Dissolved Oxygen $(\mathrm{DO}, \mathrm{mg} / \mathrm{l})$ were measured by using an electronic probe (Digital DO/ Temperature Meter, Model UC-12, Central Kagaku, Co., Ltd., Japan). pH was measured by using an electrode probe (Digital pH Meter, Model UC-23, Central Kagaku, Co., Ltd., Japan). The estimation of Biochemical 
Oxygen Demand (BOD, mg/l) after 5 days $\left(\mathrm{BOD}_{5}\right)$ was analyzed after incubation of water samples for 5 days, titrimetrically by Winkler's method (Golterman et al., 1978). Nitrogen (mg/l) contents were measured by using Hatch Portable Data logging Spectrophotometer (Model DR/2010).

\section{Data Analysis}

Collected data were coded and analyzed using Statistical Package for Social Science (SPSS, 1999). Descriptive summary statistics such as proportions means and percentages were used to describe socioeconomic and health status of the study group. The differences in water quality parameters ( $\mathrm{pH}$ value, temperature, BOD, Chemical Oxygen Demand (COD) and nitrate nitrogen $\left.\left(\mathrm{NO}_{3}{ }^{-}-\mathrm{N}\right)\right)$ between the retting and non-retting water bodies were compared using Student's t-test (SAS, 1988).

\section{RESULTS AND DISCUSSION}

\section{Water quality}

All water quality parameters were significantly different $(\mathrm{p}<0.05)$ between retting yard and non retting area (Table 1). Water temperature in the retting yard ranged from $25^{\circ} \mathrm{C}$ to $28^{\circ} \mathrm{C}$. The mean water temperature in retting yard was significantly higher $(\mathrm{p}<0.05)$ than the non retting area. The DO varied from $3.8-5.8 \mathrm{mg} / \mathrm{l}$ with significantly lower $(\mathrm{p}<0.05)$ DO level recorded from retting yard (Table 1). BOD level and COD level were significantly higher $(p<0.05)$ than non retting area. This may be due to the occurrence of higher biological activity in coir retting yards. The process of retting is found to cause pollution problem in the river mouth and backwaters. Assessment of pollution due to retting of coconut husk and development of alternative retting technology was carried out by Romani and Nirmala (1989). They found that the air pollution also prevails in these areas due to the release of hydrogen sulphide, methane and carbondioxide

Table 1. Comparison of water quality parameters of retting yard and non-retting area

\begin{tabular}{llrr}
\hline Parameters $^{1}$ & & Retting yard $^{\mathbf{2}}$ & Non-retting area $^{2}$ \\
\hline Temperature $\left({ }^{\circ} \mathrm{C}\right)$ & Mean $\pm \mathrm{SD}$ & $29^{\mathrm{a}} \pm 0.04$ & $22^{\mathrm{b}} \pm 0.01$ \\
& Range & $\left(28^{\circ} \mathrm{C}-29^{\circ} \mathrm{C}\right)$ & $\left(20^{\circ} \mathrm{C}-24^{\circ} \mathrm{C}\right.$ \\
$\mathrm{pH}$ & Mean $\pm \mathrm{SD}$ & $7.2^{\mathrm{a}} \pm 0.02$ & $7.5^{\mathrm{b}} \pm 0.01$ \\
& Range & $(6.0-6.9)$ & $(7.0-8.1)$ \\
$\mathrm{DO}(\mathrm{mg} / \mathrm{l})$ & Mean $\pm \mathrm{SD}$ & $3.8^{\mathrm{a}} \pm 0.05$ & $4.5^{\mathrm{b}} \pm 0.05$ \\
& Range & $(3.0-4.2)$ & $(4.2-5.8)$ \\
$\mathrm{BOD}(\mathrm{mg} / \mathrm{l})$ & Mean $\pm \mathrm{SD}$ & $28^{\mathrm{a}} \pm 0.2$ & $28^{\mathrm{b}} \pm 0.5$ \\
& Range & $(22-29)$ & $(26-29)$ \\
$\mathrm{COD}(\mathrm{mg} / \mathrm{l})$ & Mean $\pm \mathrm{SD}$ & $42^{\mathrm{a}} \pm 0.5$ & $4^{\mathrm{b}} \pm 0.5$ \\
& Range & $(38-44)$ & $(7-3.8)$ \\
$\mathrm{NO}_{3}-\mathrm{N}$ & Mean $\pm \mathrm{SD}$ & $0.19^{\mathrm{a}} \pm 0.2$ & $0.08^{\mathrm{b}} \pm 0.08$ \\
& Range & $(0.17-0.19)$ & $(0.07-0.09)$ \\
\hline
\end{tabular}

${ }^{2}$ Within rows, the means not sharing a common superscript are significantly different $(p<0.05)$. Respective ranges are shown within parantheses. 


\section{Literacy and education levels}

Distribution of household members by educational level clearly shows that a large proportion of the study population $(95 \%)$ had at least some formal education. Those with primary education constituted $89 \%$. Nevertheless, despite the large proportion who attained primary education, the percentage that proceeded to secondary and tertiary level education were $9 \%$ and $2 \%$, respectively (Fig. 1 ).

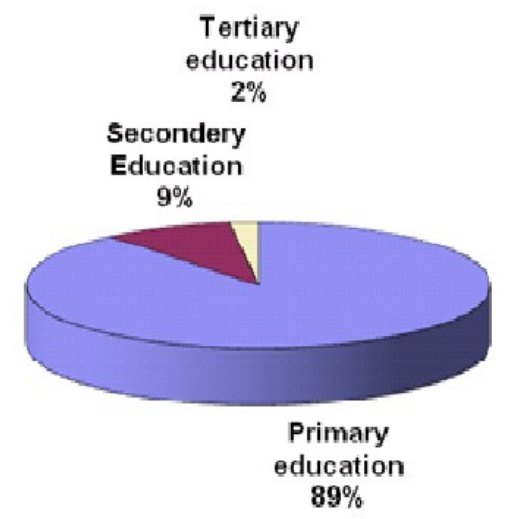

Fig. 1. Distribution of literacy level of the coir retting involved family

\section{Occupational status}

Fishing is the major economic activity in the study area. Fishing and fishing related activities constituted $38 \%$, while significantly higher number of females $(72 \%)$ were involved in coir retting industry and rope making industry (Table 2). However, when fishermen do not fish from May to September due to the effects of monsoon rains, coir retting is the major income of these families. This study revealed that most of the women engaged in this employment were those who had a low level of education. A low level of education attainment has led to unskilled labour. On the other hand, coir retting increases the household income; which is one of the key determinants of nutrition and health of the family members (Crawford et al., 1995).

Table 2. Occupational status of the coir retting involved families

\begin{tabular}{lcc}
\hline Occupational status & Male & Female \\
\hline Fishing & 53 & - \\
Fishing related activity & 08 & 03 \\
Coir making & 10 & 47 \\
Rope making & - & 15 \\
Unemployed & 15 & 21 \\
\hline
\end{tabular}

\section{Socioeconomic status}

A large proportion of the total household members (33\%) were children under 15 years, followed by the age range between $15-25$. The average house-hold size was 4.5 . Ninety five percent of the households were Buddhists while the balance was Catholics. 
Among the 35 families, $43 \%$ belonged to Rs. 4000.00 - 6000.00 monthly income group and $14 \%$ belong to very low income group and only $9 \%$ earned above Rs. 6000.00 per month (Table 3). National official poverty line for August 2011 is Rs. 3241.00 (Anon, 2011), which shows that they are poor. This low income was mainly due to poor marketing facilities for their coir products. In addition, they were not saving money for future use, which could be contributed to low education level.

The daily net income of the coir retting involved family was Rs. 612.50. However, they get engaged in this process only for 12 - 15 days per month due to lack of raw materials, marketing problems and bad weather conditions. Coconut husks are obtained from outside areas and bought at Rs. 1.75 per husk. After processing, they earn Rs. 5.25 from one husk. An average of two hundred rotten husks were beaten by a woman a day from which Rs. 918.75 is earned.

Table 3. Distribution of monthly income level of the coir retting involved families

\begin{tabular}{lcc}
\hline Monthly Income & No of families & Percentage (\%) \\
\hline $0-2000$ & 5 & 14 \\
$2000-4000$ & 12 & 34 \\
$4000-6000$ & 15 & 43 \\
$6000-8000$ & 2 & 6 \\
8000 above & 1 & 3 \\
\hline
\end{tabular}

A list of 10 items was selected including house type, availability of electricity, sewing machine, television, bicycle and motor bike (Table 4). Material style of life, a method of measuring wealth based on the presence or absence of household possessions, can be an indicator of relative wealth or social status in a community (Pollnac \& Crawford, 2000). Results revealed that $100 \%$ of the families had their own houses but $51 \%$ of houses were incomplete. When their assessments were compared, a high percentage of families (57\%) had televisions for their houses. In addition, most of the houses ( $89 \%)$ had electricity.

Table 4. Condition of houses and assets of coir retting involved families

\begin{tabular}{lcc}
\hline Item & No of Families & Percentage \\
\hline Ownership & 35 & 100 \\
Roofed & 29 & 83 \\
Incomplete houses & 18 & 51 \\
Thatched & 0 & 0 \\
Asbestos & 6 & 17 \\
No house & 0 & 0 \\
Electricity supply & 31 & 89 \\
Saving Machine & 8 & 23 \\
Television & 25 & 71 \\
Bicycle & 8 & 23 \\
Motorbike & 3 & 8 \\
\hline
\end{tabular}

Analysis of health aspects clearly showed that the majority of the coir retting involved families members $(90 \%)$ suffered from eye disease, skin disease, back pain, headache, respiratory disease and many other diseases (Table 5). Back pain and headache were observed as the major diseases in the target group. Women often stand knee-deep in the pits 
containing polluted water for a few hours in removing rotten husks. The exposure of the women to polluted waters and their long hours standing have affected their health significantly.

Table 5. Distribution of household health status of coir retting involved families

\begin{tabular}{lcc}
\hline Name of disease & No. of persons & Percentage (\%) \\
\hline Eye disease & 4 & 7 \\
Skin disease & 6 & 10.5 \\
Back pain & 14 & 24.5 \\
Headache & 15 & 26 \\
Respiratory disease & 5 & 8.8 \\
Other & 7 & 12.2 \\
Total & 51 & 90 \\
\hline
\end{tabular}

Several studies and scientific literature have identified Socio-Economic Status (SES) as a powerful determinant of health status (Adler \& Ostrove, 1999). In fact, today health disparities as a result of SES have become important issues of public health concern worldwide (Kim et al., 2004). In addition, water pollution of the retting yards may adversely affect their health status (Romani \& Nirmala, 1989).

\section{CONCLUSIONS}

Results of this study showed that majority of the households fall within the low SES with deepening poverty background showed by low educational status and occupational status. It is therefore recommended that introduction of new techniques as well as providing a good market for these products may improve income level of the target group. In addition, improved technology should be developed to arrest the disease conditions observed among women involved in coir retting.

\section{ACKNOWLEDGEMENT}

Authors are thankful for UNESCO for financial assistance.

\section{REFERENCES}

Adler, N.E. and Ostrove, J.M. (1999). Socioeconomic status and health what we know and what we do not know. Ann. N.Y. Academy Science. 896, 3-5.

Anonymous (2009). Sri Lanka Fisheries Year Book. National Aquatic Research and Development Agency, Crown Island, Mattakkuliya, Colombo 15, Sri Lanka.

Anonymous (2011). Department of Census and Statistics. P.O. Box 563, Colombo, Sri Lanka. http://www.statistics.goverty/monthly poverty/index.htm. 
Crawford, P.B. Obarzarck, E., Scheiber, G.B., Barvier, P., Goldman, S. and Fredrick, M.M. (1995). The effect of race, household income and parental education on nutrition intakes of 9 - and 10-year old girls. NILBI Growth and Health Study. Ann. Epidemiol. 5, 360-368.

Golterman, H.L., Clymo, R.S. and Ohnstad, M.A.M. (1978). Methods for physical and chemical Analysis of Fresh waters. IBP Hand book No. 8 Black well Scientific Publications, Oxford, London.

Immanuel, G., Dhanusa, R., Prema, P. and Pelavesam, A. (2006). Effect of different growth parameters on endoglucanase enzyme activity by bacteria isolated from coir retting effluents of estuarine environment. Int. J. Environ. Sci. Tech. 3(1), 25-34.

Kim, S., Symons, M. and Popkin B.M. (2004). Contrasting socioeconomic profiles released to healtheir lifestyle in China and united status. Am. J. Epidemiol. 59, 184 - 191.

Oxfram Humanitarian Field Studies, (2006). The Coir Industry in the Southern Province of Sri Lanka. Suite 20, 266 Banbury Road, Oxford.

Pollnac, R.B. and Crawford, B. (2000). Assessing behavioural aspects of coastal resource use. Coastal Resources Center, University of Rhode Island, Report, 2226.

Romani K.N. and Nirmala, E. (1989). Assessment of Pollution due to Retting of Coconut husk and Development of Alternative Retting Technology, Final Report, CWRDM.

SPSS Statistical Software. (1999). SPSS Base 11.5 for windows. SPSS, Inc., Chicago, IL

Statistical Analysis System, (1988). SAS institute Inc. Cary, NC, U.S.A.

Woolley, T., Kimmins, S., Harrison, P. and Harrison, R. (1997). Green Building Hand book. A guide to building products and their impact on the environment Green building. Digest. Spon. Press. 